\title{
Intravenous leiomyomatosis without extrapelvic involvement
}

\author{
Rodrigo Pereira Mata, ${ }^{1}$ Cecília Urzal, ${ }^{1}$ Ana Isabel Belo, ${ }^{2}$ Fernando Guerreiro ${ }^{1}$
}

'Obstetrics and Gynecology Department, Centro Hospitalar do Algarve EPE, Portimão, Faro, Portugal

${ }^{2}$ Anatomical Pathology, Synlab, Lisbon, Portugal

\section{Correspondence to} Dr Rodrigo Pereira Mata; rpereiramata@gmail.com

Accepted 7 March 2020

\section{DESCRIPTION}

A 41-year-old healthy woman, gravida 2 para 2 , was referred to our gynaecological outpatient department due to her history of menorrhagia, with 6 months of evolution, and with consequent anaemia (haemoglobin-95 g/L). During gynaecological examination, a 12 -week uterus was palpable and a pelvic ultrasound showed an augmented uterus $(104 \times 74 \times 60 \mathrm{~mm})$ with multiple submucous myomas (the larger with $22 \mathrm{~mm}$ ). The patient started taking ulipristal acetate to achieve uterine bleeding control while waiting for hysteroscopy. Three weeks after, she was admitted to the emergency department due to ongoing heavy uterine bleeding with a symptomatic anaemia (haemoglobin-88 $\mathrm{g} / \mathrm{L})$. Facing this medical resistant intense uterine bleeding and no fertility preservation desire, total hysterectomy was performed after transfusion of one unit of red blood cells.

Surgical examination showed a slightly increased uterus, without visible myomas, and with macroscopically normal adnexa. Histological examination revealed multiple macroscopic intracavitary/ intramural myomas $\leq 1 \mathrm{~cm}$ (figure 1 ); microscopy of these myomas displayed features compatible with intravenous leiomyomatosis (IVL) (figure 2A,B). Echocardiogram, high-resolution pulmonary CT and pelvic MRI were sequentially performed but showed no additional findings. The patient started

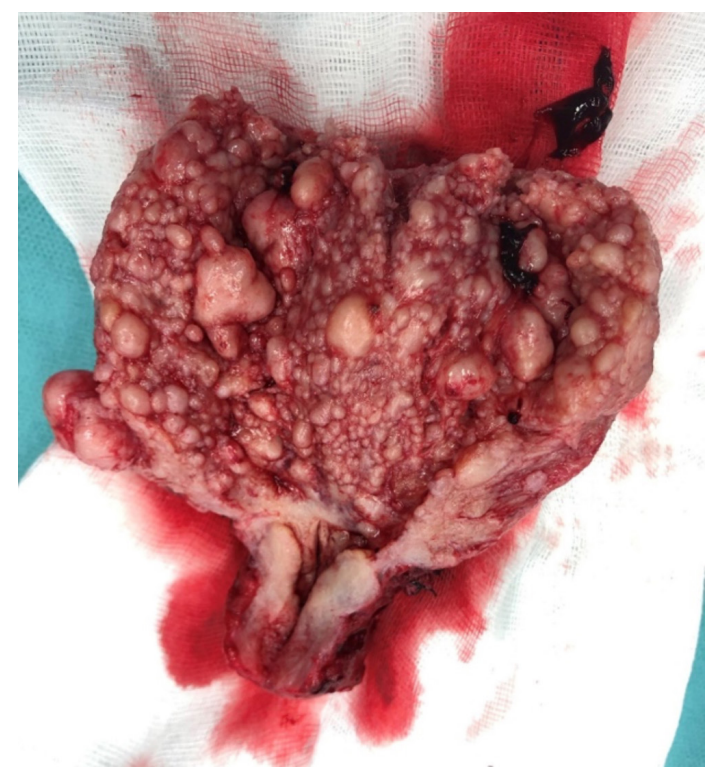

Figure 1 Interior part of surgical specimen, showing a particular aspect of the endometrial cavity occupied by multiple nodular structures.
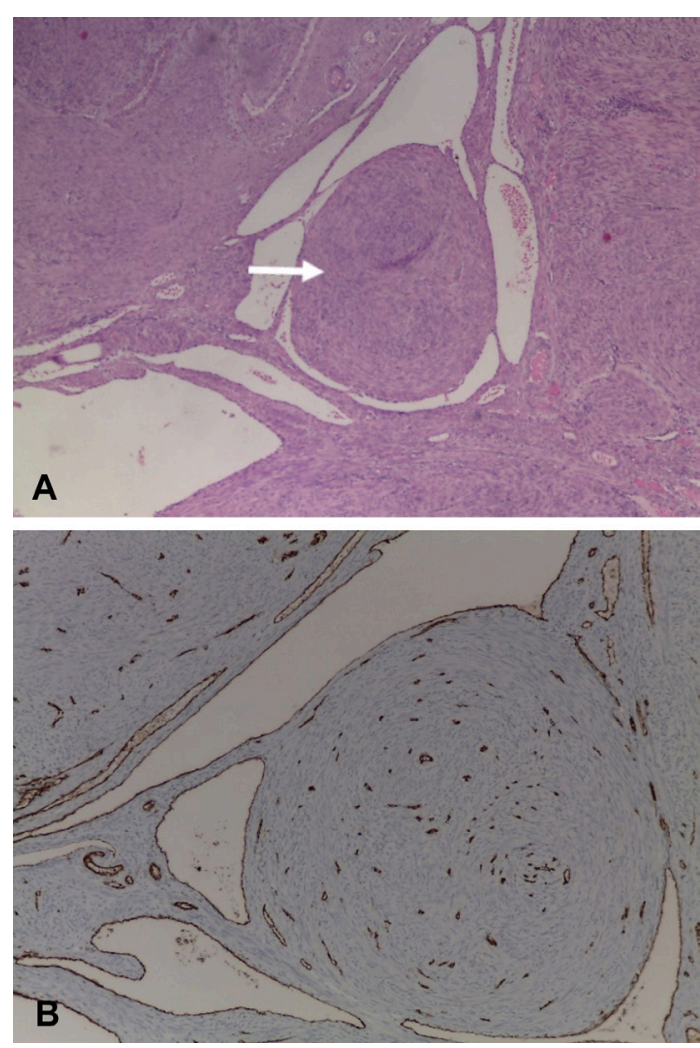

Figure 2 (A) Nodular smooth muscle tumour (H\&E, $\times 4$ ). (B) Endothelial vascular walls stained with CD31 marker, confirming the intravenous component of leiomyomatosis $(\times 10)$.

taking continuous oral progestogen and remains asymptomatic 6 months after surgery.

IVL is a rare condition with about 300 cases reported before 2020 and since its first description in 1896 by Birch-Hirschfeld. ${ }^{1}$ Although histologically benign, this uterine neoplasm is characterised by venous smooth muscle nodular growing with potential extension to the inferior vena cava, right heart cavities and pulmonary arteries, where it can lead to embolic phenomena, heart blockade and death. Most reported cases describe diagnosis in the fifth decade of life with special incidence in the perimenopausal stage, although 20-80-year-old women have been diagnosed. ${ }^{2}{ }^{3}$ Because in its early stages IVL can be asymptomatic, or its clinical features can overlap those of myomatous uterus (hypermenorrhoea, pelvic discomfort, pelvic mass), it can be underdiagnosed or diagnosed after cardiac/vascular involvement. ${ }^{2-5}$ Complete resection of all existing tumours is the adequate treatment for IVL, with total hysterectomy and bilateral salpingo-oophorectomy being recommended to 
treat pelvic disease. ${ }^{246}$ Bilateral oophorectomy is controversial if the disease is confined to the uterus in $<40$-year-old women. ${ }^{7}$ Early uterine histological diagnosis should prompt proper investigation to exclude extrapelvic involvement; echocardiography is the gold standard to identify intracardiac leiomyomatosis and thoraco-abdominal-pelvic CT or MRI is recommended to evaluate the extent of tumour involvement, with vascular reconstruction allowing determining the location, size and full extension pathway of IVL lesions. ${ }^{2}{ }^{3}$ The recurrence rate may be as high as 30\% and it depends on the age of the patient and initial size of the tumour. ${ }^{2}$ To reduce this risk, drug therapy with gonadotropin-releasing hormone agonists, tamoxifen or medroxyprogesterone is being controversially proposed, mainly in cases of incomplete resection. Long-term follow-up with

\section{Learning points}

- Intravenous leiomyomatosis is a rare condition, difficult to suspect before gynaecological surgery and when there is no extrapelvic involvement.

- When diagnosis is accidentally made following hysterectomy, clinical investigation should be performed for the early diagnosis of potentially fatal cardiac and vascular involvement.

- Gynaecological long-term follow-up must be offered to prevent fatal recurrence events.
CT or MRI is advised by most authors, and in the absence of periodicity recommendations, annual evaluations are currently proposed, with recurrences described up to 15 years after diagnosis and resection. ${ }^{267}$

Contributors RPM: surgical intervention, planning, conducting and reporting of the work; CU: patient follow-up and review of the work; AIB: histological diagnosis and review of the work; FG: surgical intervention and review of the work.

Funding The authors have not declared a specific grant for this research from any funding agency in the public, commercial or not-for-profit sectors.

Competing interests None declared.

Patient consent for publication Obtained.

Provenance and peer review Not commissioned; externally peer reviewed.

\section{REFERENCES}

1 Birch-Hirschfeld FV. Lehrbuch Der Pathologischen Anatomie. F. C. W. V. Leipzig, 1986.

2 Liu N, Long Y, Liu Y. Intravenous leiomyomatosis: case series and review of the literature. J Int Med Res 2020;48:030006051989688.

3 Li B, Chen X, Chu Y-D, et al. Intracardiac leiomyomatosis: a comprehensive analysis of 194 cases. Interact Cardiovasc Thorac Surg 2013;17:132-8.

4 Konishi H, Koh I, Shiroma N, et al. Two case reports of intravenous leiomyomatosis with hyaluronan expression. Case Rep Obstet Gynecol 2018;2018:1-5.

5 Tang L, Lu B. Intravenous leiomyomatosis of the uterus: a clinicopathologic analysis of 13 cases with an emphasis on histogenesis. Pathol Res Pract 2018;214:871-5.

6 Low H-Y, Zhao Y, Huang K-S, et al. Intravenous leiomyomatosis of the uterus: a clinicopathological analysis of nine cases and literature review. Taiwan J Obstet Gynecol 2017:56:362-5

7 Du J, Zhao X, Guo D, et al. Intravenous leiomyomatosis of the uterus: a clinicopathologic study of 18 cases, with emphasis on early diagnosis and appropriate treatment strategies. Hum Pathol 2011:42:1240-6.

Copyright 2020 BMJ Publishing Group. All rights reserved. For permission to reuse any of this content visit

https://www.bmj.com/company/products-services/rights-and-licensing/permissions/

BMJ Case Report Fellows may re-use this article for personal use and teaching without any further permission.

Become a Fellow of BMJ Case Reports today and you can:

- Submit as many cases as you like

- Enjoy fast sympathetic peer review and rapid publication of accepted articles

- Access all the published articles

Re-use any of the published material for personal use and teaching without further permission

Customer Service

If you have any further queries about your subscription, please contact our customer services team on +44 (0) 2071111105 or via email at support@bmj.com.

Visit casereports.bmj.com for more articles like this and to become a Fellow 